\title{
Spiroplasma insolitum sp. nov., a New Species of Group I Spiroplasma with an Unusual DNA Base Composition
}

\author{
K. J. HACKETT, ${ }^{1 *}$ R. F. WHITCOMB,${ }^{1}$ J. G. TULLY, ${ }^{2}$ D. L. ROSE, ${ }^{2}$ P. CARLE, ${ }^{3}$ J. M. BOVÉ, ${ }^{3}$ \\ R. B. HENEGAR, ${ }^{1}$ T. B. CLARK, ${ }^{1}$ E. A. CLARK, ${ }^{1}$ M. KONAI, ${ }^{1}$ \\ J. R. ADAMS, ${ }^{1}$ AND D. L. WILLIAMSON ${ }^{4}$ \\ Insect Biocontrol Laboratory, U.S. Department of Agriculture, Beltsville, Maryland $20705^{1}$; Mycoplasma \\ Section, Laboratory of Molecular Microbiology, National Institute of Allergy and Infectious Diseases, \\ Frederick Cancer Research Facility, Frederick, Maryland $21702^{2}$; Laboratoire de Biologie Cellulaire et \\ Moléculaire, Institut National de Recherche Agronomique, 33883 Villenave d'Ornon, France ${ }^{3}$; and \\ Department of Anatomical Sciences, State University of New York, Stony Brook, New York $11794^{4}$
}

\begin{abstract}
Spiroplasma strain M55, isolated from a fall flower in Maryland, showed patterns of partial serological cross-reactivity with the other seven group I spiroplasma subgroups but was not serologically related to other spiroplasma groups. Strain M55 had less than 70\% DNA-DNA homology with group I subgroups previously assigned binomial names and was unique among the group I subgroups in possessing a higher guanine-pluscytosine content in its DNA ( $28 \pm 1 \mathrm{~mol} \%$, versus $26 \pm 1 \mathrm{~mol} \%$ for other group I subgroups). The genome size was $1,850 \mathrm{~kb}(1,233 \mathrm{MDa})$. Extensive data on the metabolism of strain M55 and the community ecology of this and similar strains have been reported. These circumstances fulfill criteria proposed by the Subcommittee on the Taxonomy of Mollicutes for elevation of mollicute subgroups to species status. Accordingly, strain M55 was characterized according to proposed minimal standards for species descriptions. Cells of strain M55 were shown by light microscopy to be helical, motile filaments. Electron microscopy showed that the cells possessed no cell wall and were bounded by a single membrane; they were insensitive to penicillin $(1,000 \mathrm{U} / \mathrm{ml})$. Strain M55 was culturable in M1D and SP-4 liquid media under aerobic (with or without enhanced carbon dioxide) or anaerobic environments. Optimal growth occurred at $30^{\circ} \mathrm{C}$, with a doubling time of $7.2 \mathrm{~h}$. Growth occurred from 15 to $37^{\circ} \mathrm{C}$ but not at 10 or $42^{\circ} \mathrm{C}$. Strain M55 did not utilize urea or hydrolyze arginine but did produce acid from glucose. As a consequence of these studies, strain M55 is designated the type strain (M55 ${ }^{\mathrm{T}}$; ATCC $33502^{\mathrm{T}}$ ) of a new species, Spiroplasma insolitum.
\end{abstract}

Spiroplasmas of group I (1), many of which are intricately integrated into the life cycles of plants and insects, have proved to be of great interest to both basic and practical research. Three members of this group, spiroplasma subgroups I-1 (Spiroplasma citri [27]), I-3 (S. kunkelii [39]), and I-8 (S. phoeniceum [28]) account for all known plant-pathogenic spiroplasmas, and a fourth, the subgroup I-5 spiroplasma (24), is associated with plant-sucking insects in Taiwan. Further, investigations into a vascular plant disease led to the discovery of the subgroup I-7 spiroplasma in Jamaica (11); the exact habitat of this spiroplasma has yet to be elucidated. The subgroup I-2 spiroplasma ( $S$. melliferum [10]) is associated with bees, for which it is pathogenic (7). Another spiroplasma, the subgroup I-4 spiroplasma (25), was ostensibly isolated from the rabbit tick Haemaphysalis leporispalustris in Montana. However, because this spiroplasma was isolated only once, its true habitat must be considered uncertain.

Against this backdrop, the subgroup I-6 spiroplasmas, which appear to exist in a more ecologically simple, plant surface-insect gut cycle (8) (type A of Clark [9]), are unusual. This spiroplasma has been found to be widely distributed on fall flowers in old fields in Maryland and in a large number of the insect species that visit such flowers. Hackett et al. (18), in a detailed study of the community ecology of this spiroplasma, concluded that various types of carriage must occur, including transient passive carriage as well as lateral (although perhaps local) dissemination to, presumably, at least one insect species that may serve as the overwintering

\footnotetext{
* Corresponding author.
}

reservoir and that initiates the annual cycle in the spring or summer. In the course of routine characterization of group I spiroplasma subgroups, it was discovered (5) that the guanine-plus-cytosine $(\mathrm{G}+\mathrm{C})$ content of the subgroup I-6 spiroplasma was significantly higher than those of other members of the group ( $28 \pm 1$ mol\% for subgroup I-6 versus $26 \pm 1$ mol\% for the other members of the group). This genomic characteristic, together with its ecological characteristics (a broad host range and widespread association with fall flowers), made this subgroup anomalous within the group I spiroplasmas.

Although, in general, it may not be feasible to designate specific names for mollicutes that form arrays of strains with different degrees of genomic relatedness, the International Committee for Systematic Bacteriology Subcommittee on the Taxonomy of Mollicutes discussed specific cases in which elevation of subgroups to species would be appropriate $(21,38)$. Four criteria appeared to be important. These criteria were as follows: (i) the importance of the organism to basic or applied research should justify the existence of a specific binomial; (ii) the organism should have no more than $70 \%$ homology with other named species; (iii) the organism should be shown to be a representative of a cluster of organisms that have similar properties and that can be clearly identified and separated from other related organisms; and (iv) the ecology of the organism should be sufficiently defined. It was agreed that if these criteria were met, representative strains could be appropriate candidates for examination by the proposed criteria for species descriptions for members of the class Mollicutes. In this article, we report the results of taxonomic studies of strain M55 undertaken to satisfy these proposed requirements. Our results support 
elevation of strain M55, the representative strain $\left(M 55^{T}\right)$ of spiroplasma subgroup I-6, to new status as the species Spiroplasma insolitum.

\section{MATERIALS AND METHODS}

Spiroplasma strains. Techniques for isolation of spiroplasmas from flowers and insects, primarily developed by Clark and colleagues, have been described elsewhere $(7,17,41)$. Strain M55 was cultivated from a fall flower (Compositae: Bidens sp.) collected in Maryland (41). Some of the genomic and serologic features of the strain have been reported elsewhere (34). A number of other strains and isolates were obtained from fall flowers (e.g., strains M52 from Eupatorium hypossifolium and M58 from Oenothera biennis [41] and isolates JPW10 from E. maculatum and SOL12 from a Solidago sp. [18]) and from the insects that visit the flowers (e.g., isolates from flies [FLY1G, Bombyliidae: Sparnopolius confusus], bees [BEE6G, Andrenidae: Pseudopanurgus sp.; and LB11G, Megachilidae: Megachile inimica], and butterflies [MRCHAG, Danaidae: Danaus plexippus; TS21G, Papilionidae: Pterourus glaucus; SP1G, Pterourus troilus; CS1G, Pieridae: Colias philodice; and YPO1G, Yponomeutidae: Atteva sp.] [6, 18]). The following Subgroup I-6 strains and isolates have also been obtained $(6,17$, 18) from other beetles: CP-5 from the gut of a Chauliognathus pennsylvanicus (Cantharidae) adult, Tri-1 from a squashed preparation of a beetle triungulin (Meloidae) phoretic on a wasp, and ET-1 from the gut of a flower fly (Syrphidae: Eristalis transversus).

Strains, including the proposed type strain M55, were purified by conventional filtration-cloning techniques (30); some isolates were examined serologically without cloning. Representative strains of recognized groups and subgroups $(16,33,43)$ were used as reference strains.

Culture media and cultivation techniques. Primary isolation of strain M55 was accomplished (41) in M1D (37) broth cultures maintained at $30^{\circ} \mathrm{C}$. After several passages, the isolate was triply cloned and designated a strain; this was then passaged and lyophilized. For characterization, the lyophils were resuscitated in M1D broth and passaged. Other culture media used included SP-4 (35) and SM-1 (37) broths, the Edward formulation of conventional mycoplasma medium (HSI) containing $20 \%$ horse serum $(12,37)$, and serum fraction broth with $1 \%$ bovine serum fraction (32). Solid formulations were prepared by adding Noble agar (Difco Laboratories, Detroit, Mich.) to a final concentration of 0.8 to $2.25 \%$ in the liquid media. Cultures on solid media were incubated at $30^{\circ} \mathrm{C}$ either aerobically (with or without supplemental carbon dioxide $\left[\begin{array}{lll}5 \% & \mathrm{CO}_{2} & \text {; Carbon Dioxide }\end{array}\right.$ GasPak system; BBL Microbiology Systems, Cockeysville, Md.]) or anaerobically (4 to $7 \% \mathrm{CO}_{2}, 25$ to $35 \% \mathrm{H}_{2},<1 \% \mathrm{O}_{2}$; (BBL Anaerobic GasPak system). The cultures were tested for insensitivity to penicillin $\mathrm{G}$ by passage in M1D broth with $1,000 \mathrm{U}$ of penicillin $\mathrm{G}$ per $\mathrm{ml}$.

Temperature requirements for growth (23) were assessed by inoculating strain CN-5 into M1D broth. The inoculated cultures were incubated at $5,10,15,20,25,30,32,37$, or $42^{\circ} \mathrm{C}$. Growth was assessed by observing medium indicator change and by microscopic examination of the cultures. Doubling times at each temperature were determined by fitting temperature-time curves to a logistic growth equation (23).

Morphological studies. Filtration of strain M55 through pores of different sizes $(450,300,220$, and $100 \mathrm{~nm})$ was determined by methods described previously (30). Cells of strain M55 in logarithmic phase were examined by dark-field microscopy at a magnification of $\times 1,250$. For electron microscopy (10), pelleted cells of strain M55 were fixed for $2 \mathrm{~h}$ in 3\% glutaraldehyde in phosphate buffer $(\mathrm{pH} 7.3)$ supplemented with $0.25 \mathrm{M}$ sucrose, postfixed in Palade-buffered $1 \%$ osmium tetroxide for $1 \mathrm{~h}$, dehydrated in acetone, and embedded in Spurr low-viscosity embedding medium. They were later cut into 60 - to 90 -nm-thick sections and stained with $1 \%$ aqueous uranyl acetate and Reynolds' lead citrate.

Sterol requirement. Sterol requirements for growth were assayed by comparing the amounts of growth on SP-4 medium with and without supplements of fetal bovine serum (31).

Tests of biological and biochemical properties. Substrate utilization was determined by amending conventional mycoplasma broth medium containing serum fraction with urea, arginine, or glucose (10); growth was assayed by determination of color-changing units per milliliter. Hemadsorption (adsorption of erythrocytes to spiroplasma colonies) (14) and film (cholesterol and phospholipid positive) and spot (inorganic precipitates formed) reactions on solid media (13) were assessed.

Serological tests. Strain M55 was assayed serologically in M1D or SP-4 medium by three standard techniques: disk growth inhibition (40), spiroplasma deformation (44), and metabolism inhibition (42). Specific antiserum was obtained from rabbits hyperimmunized with antigen from strain M55 (44). Antisera to established Spiroplasma species and groups from reference collections at the Agricultural Research Center in Beltsville, Md., and the National Institute of Allergy and Infectious Diseases laboratory in Frederick, Md., were used for serological comparisons $(16,33)$.

Genomic analysis. The methods used for extraction and purification of genomic DNA from spiroplasmas have been described elsewhere (3). Independent estimates of the $\mathrm{G}+\mathrm{C}$ content of purified DNA of strain M55 and seven other related strains and isolates were obtained by buoyant-density, melting point temperature, and high-performance liquid chromatography techniques $(2,4,22)$. The genome size was determined by pulsed-field gel electrophoresis as described by Grau et al. (15).

\section{RESULTS AND DISCUSSION}

Cultural and morphological properties. Strain M55 grew well in liquid SM-1, M1D, and SP-4 media, forming diffuse colonies (Fig. 1) on solid SP-4 medium with a 0.8 or $2.25 \%$ agar concentration. In these colonies, small central zones were surrounded by even smaller satellite colonies (Fig. 1). "Fried-egg" colonies were never observed. On horse serum agar plates containing $0.8 \%$ agar, colony growth was best when the strain was incubated aerobically. Strain M55 did not produce the film and spot reaction and did not hemadsorb guinea pig erythrocytes. The strain grew in the Edward formulation; bovine serum fraction broth did not support continued growth. Strain M55 grew from 15 to $37^{\circ} \mathrm{C}$; the doubling times were $19.3 \mathrm{~h}$ at $20^{\circ} \mathrm{C}, 9.0 \mathrm{~h}$ at $25^{\circ} \mathrm{C}, 7.2 \mathrm{~h}$ at $30^{\circ} \mathrm{C}, 7.6 \mathrm{~h}$ at $32^{\circ} \mathrm{C}$, and $42.3 \mathrm{~h}$ at $37^{\circ} \mathrm{C}$. No growth occurred at 10 or $42^{\circ} \mathrm{C}$. The optimum growth temperature was therefore $30^{\circ} \mathrm{C}$.

Dark-field microscopy of logarithmic-phase cultures of strain M55 showed numerous long helical, flexing, and translationally motile filaments, usually with eight or more turns. Electron microscopy (Fig. 2) showed cells with no evidence of cell wall or periplasmic fibrils. Cells were delimited by a single cytoplasmic membrane. They were 


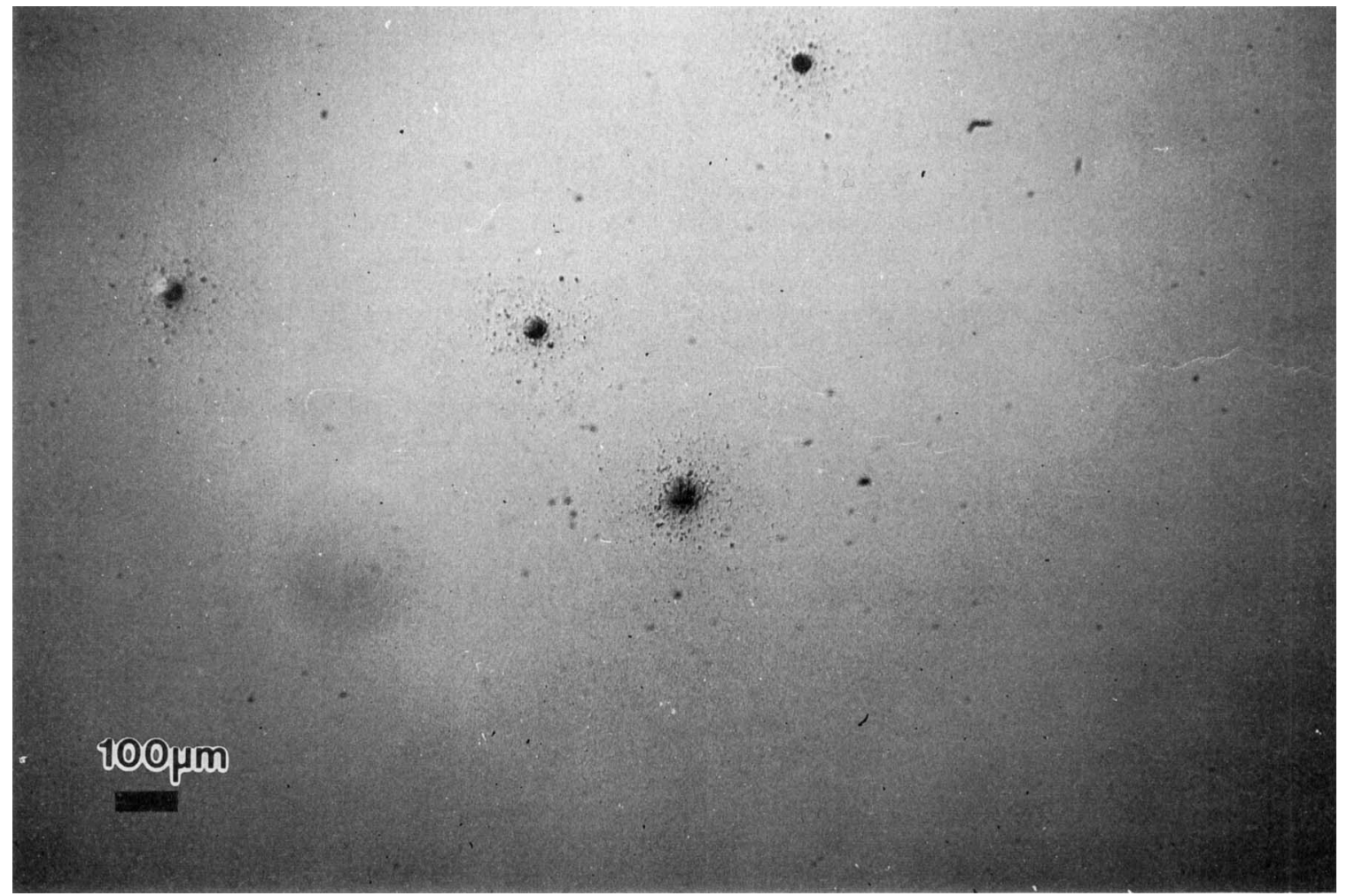

FIG. 1. Colonies of strain $\mathrm{M}^{\mathrm{T}} 5^{\mathrm{T}}$ on horse serum (HSI) agar $\left(0.8 \%\right.$ Noble agar) after 10 days of incubation at $30^{\circ} \mathrm{C}$ in an aerobic environment.

filterable (with a 2-log-unit loss of titer) through 220- but not 100 -nm membranes.

Physiological properties. Urea was not utilized. Although strain M55 was reported to be an arginine metabolizer (33), we detected no such activity. Strain M55 did ferment glucose with production of acid. Acidification of media was, however, extremely modest, with the final $\mathrm{pH}$ of liquid medium cultures rarely falling below 5.9.

Strain M55 did not grow in SP-4 base broth alone; it did grow in basal medium supplemented with 5 to $20 \%$ fetal bovine serum (Table 1). These responses are typical of organisms that are cholesterol dependent.

Serologic studies. Growth inhibition, metabolism inhibition, and spiroplasma deformation tests, as reported previously $(16,33)$, demonstrated that strain M55 was serologically unrelated to other spiroplasma groups. Reciprocal deformation and metabolism inhibition tests indicated (16, 33 ) that this subgroup, like the other group I subgroups, had complex patterns of interrelatedness with other subgroups.

Genomic studies. The genome size as determined by PFGE was $1,850 \mathrm{~kb}(1,233 \mathrm{MDa})$. Previously published data (22) indicate that subgroup I-6 spiroplasmas have no more than $70 \%$ homology with other named group I subgroups.

The $\mathrm{G}+\mathrm{C}$ base compositions (Table 2) of the DNA of strain M55 determined by buoyant-density, melting temperature, and high-performance liquid chromatography techniques were $28.2,28.9$, and $27.7 \mathrm{~mol} \%$, respectively. For other strains related to M55, the average was 28.1 to 28.2 mol\%.

Phylogenetic reconstructions now emerging (36) suggest that $\mathrm{G}+\mathrm{C}$ composition is not particularly conserved and may be subject to pressures that change as prokaryotes move from one habitat to another. It would be of great interest to have a detailed phylogeny of group I strains in order to deduce the position of subgroup I-6 with respect to the other subgroups. It is interesting that all group I organisms belong (36) to a cluster of slowly growing spiroplasmas that have narrow temperature tolerances (23).

Habitat. Strain M55 and numerous other strains have been isolated from fall flowers in Maryland. Similar strains have been isolated from insects attending the flowers, which must serve as major reservoirs for transmission of spiroplasmas among insects (18). Although these studies focused to a large extent on a diverse assemblage of summering hosts, recent evidence (19) suggests that elaterid beetles, e.g., Conoderus lividus or Melanotus communis, may be winter reservoirs. Whatever the details of reservoir maintenance are, this spiroplasma's ability to survive on flower surfaces and its ability to be transmitted among many insects visiting these flowers are salient features of the organism's life history (17). Butterflies collected from flowers with the highest levels of spiroplasma occurrence tended to have the highest infection frequencies. Although a cause-and-effect relationship cannot be proved by such evidence, the importance of nectar as a medium for the dissemination of spiroplasmas among insects is strongly suggested. Although no unusual pathways were discovered in extensive studies (26) of the metabolism of strain M55, physiological factors such as tolerance to $\mathrm{pH}$ extremes may be involved in host specificity. For example, this spiroplasma does not grow well below $\mathrm{pH} 5.9$ or above $\mathrm{pH} 9.1$ (17); beetles with gut $\mathrm{pHs}$ outside this range may be unsuitable as hosts.

Overall, elaterid beetles or other insects, as potential overwintering hosts, may be important in defining the distri- 


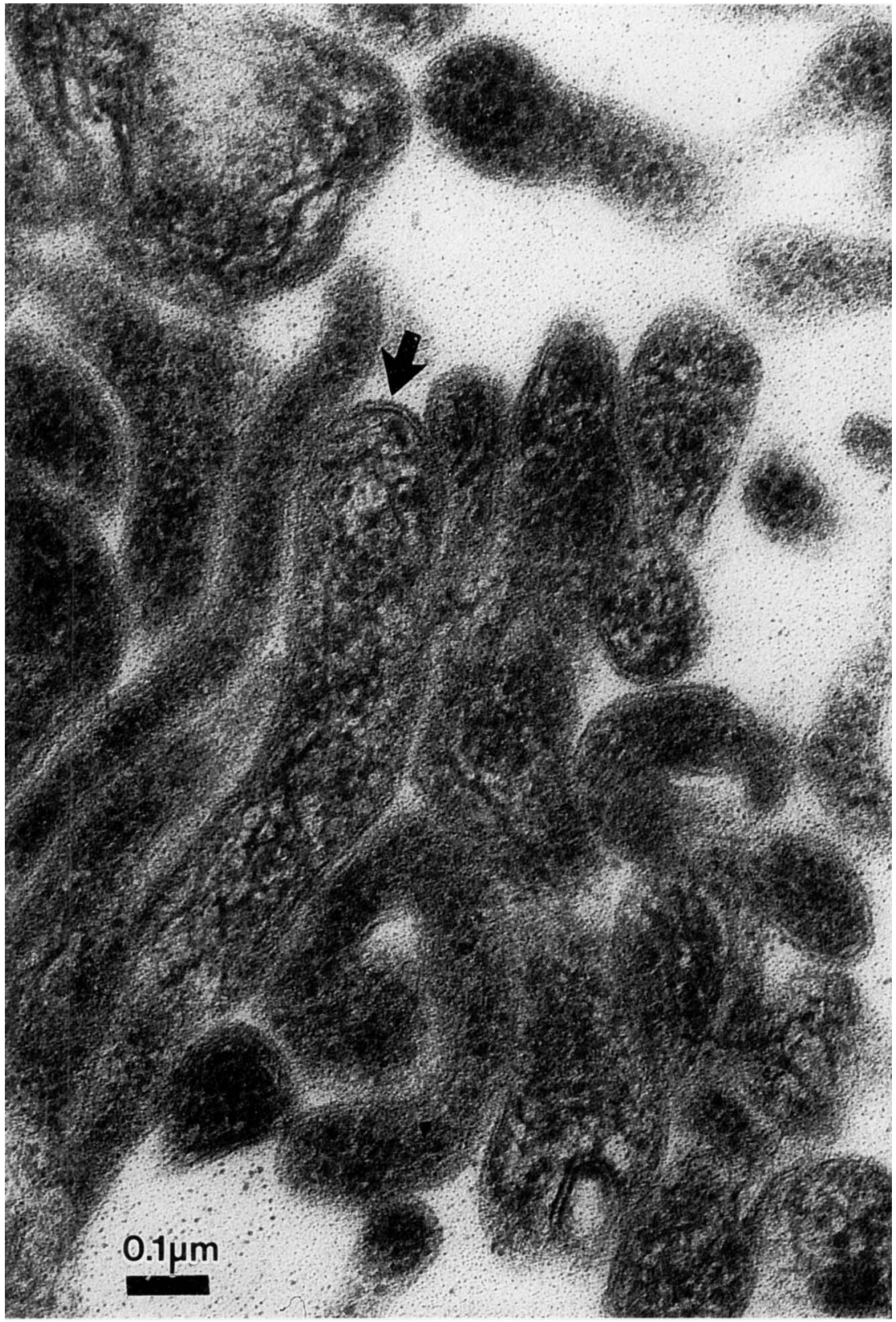

FIG. 2. Electron micrograph of a sectioned and stained cell pellet of strain M55 ${ }^{\mathrm{T}}$. Sections were stained with $2 \%$ aqueous uranyl acetate and Reynolds' lead citrate. The arrow indicates the unit membrane.

TABLE 1. Growth response of strain $M 55^{\mathrm{T}}$ to serum supplements

\begin{tabular}{lcc}
\hline Broth & $\begin{array}{c}\text { Final concn (\%) } \\
\text { of fetal bovine } \\
\text { serum }\end{array}$ & $\begin{array}{c}\text { No. of } \\
\text { organisms } \\
(\mathrm{CCU} / \mathrm{ml})^{a}\end{array}$ \\
\hline SP-4 base broth with no supplement & 0 & $10^{1}$ \\
SP-4 base broth with fetal bovine & 1 & $10^{1}$ \\
serum supplement & 5 & $10^{6}$ \\
& 10 & $10^{7}$ \\
\hline
\end{tabular}

${ }^{a}$ Determined after 7 days of incubation at $30^{\circ} \mathrm{C}$. CCU, color-changing units. bution of this spiroplasma, but the presence of (physiologically acceptable) flower-visiting insects may be critical in defining its abundance. The appearance of this spiroplasma on the surfaces of fall flowers may be a consequence of elaterid beetle visitation to these flowers combined with dissemination, by transient gut infections, among the large number of suitable insects visiting these flowers.

The butterfly and nectar association of this spiroplasma may even be important on a global scale. The subgroup I-6 spiroplasma is of considerable interest because of its isolation from the monarch butterfly, D. plexippus (17). This butterfly migrates long distances in North America and sometimes reaches Europe, thereby providing a potential avenue for spiroplasma dissemination. 
TABLE 2. $\mathrm{G}+\mathrm{C}$ contents of subgroup I-6 strains

\begin{tabular}{|c|c|c|c|c|c|}
\hline \multirow{2}{*}{$\begin{array}{l}\text { Strain or } \\
\text { isolate }\end{array}$} & \multicolumn{3}{|c|}{$\begin{array}{l}\text { Mean } \mathrm{G}+\mathrm{C} \text { content (mol\%) } \\
\text { as determined by }{ }^{a}:\end{array}$} & \multirow{2}{*}{$\begin{array}{l}\text { No. of } \\
\text { values }^{b}\end{array}$} & \multirow{2}{*}{$\begin{array}{l}\text { Avg } \mathrm{G}+\mathrm{C} \text { content } \\
(\mathrm{mol} \%) \text { for all } \\
\text { techniques }^{c}\end{array}$} \\
\hline & $\begin{array}{l}\text { Buoyant } \\
\text { density }\end{array}$ & $\begin{array}{l}\text { Melting } \\
\text { temp }\end{array}$ & HPLC & & \\
\hline \multicolumn{6}{|l|}{ Strains } \\
\hline M55 & 28.2 & 28.9 & 27.7 & 32 & 28.2 \\
\hline M52 & 27.7 & 28.2 & ND & 4 & 28.1 \\
\hline M58 & 28.4 & 28.9 & ND & 3 & 28.6 \\
\hline \multicolumn{6}{|l|}{ Isolates } \\
\hline LB11G & 27.8 & 28.7 & 27.2 & 7 & 27.8 \\
\hline JPW10 & 28.0 & 28.7 & ND & 4 & 28.3 \\
\hline YPOIG & 27.7 & 27.4 & ND & 5 & 27.5 \\
\hline BEE6G & 27.1 & 28.0 & ND & 3 & 27.7 \\
\hline FLY1G & 27.5 & 28.4 & ND & 4 & 28.2 \\
\hline
\end{tabular}

${ }^{a}$ HPLC, high-performance liquid chromatography; ND, not determined.

${ }^{b}$ Total number for all three methods.

${ }^{c}$ Average for all eight strains and isolates, $28.1 \mathrm{~mol} \%$.

In any event, ecological studies have made strain M55 and its allies model spiroplasmas for the study of community interactions between mollicutes, insects, and plant surfaces. This ecological importance, together with an extensive study of the organism's metabolic pathways and interest in the factors responsible for determining DNA base composition, provides a strong rationale for giving a binomial name to these organisms. The isolation of many strains with similar (highly homologous) serological patterns and species-level differences in genomic homology with other group I spiroplasmas also argue for status as a separate species.

The properties of strain M55 described herein fulfill proposed criteria (20) for species of the class Mollicutes. Properties mandating assignment to this class include absence of a cell wall, filterability, lack of reversion to walled bacteria when grown in antibiotic-free media, and penicillin resistance. The requirement of strain M55 for sterol, its inability to utilize urea, and its helicity and motility place this strain in the family Spiroplasmataceae (29) and the genus Spiroplasma. Suggested criteria proposed by the Subcommittee on the Taxonomy of Mollicutes for elevation of spiroplasma subgroups to species $(20,41)$ have been fulfilled herein. Accordingly, we propose the designation Spiroplasma insolitum for this organism. The taxonomic description below summarizes the properties of the organism.

Spiroplasma insolitum sp. nov. Spiroplasma insolitum (in. so.li'tum. L. adj. insolitus, unusual or uncommon; insolitum to denote unusual base composition) cells in logarithmic phase are long, motile, helical filaments that lack true cell walls. Filterable through 220 -nm membranes. Form diffuse colonies on solid medium with $0.8 \%$ Noble agar, without fried-egg morphology.

Chemoorganotroph. Acid produced from glucose. Does not utilize urea or catabolize arginine.

Film and spot reaction negative. Does not hemadsorb guinea pig erythrocytes.

Sterol requirement met by serum.

Temperature range, 15 to $37^{\circ} \mathrm{C}$; doubling time at $30^{\circ} \mathrm{C}$ optimum is $7.2 \mathrm{~h}$.

Serologically distinct from other Spiroplasma groups but cross-reacts in complex patterns of relatedness with group I subgroups.

Isolated in 1981 from a fall flower (Compositae: Bidens sp.) collected in Maryland. Similar isolates found in the hemocoel of click beetles (Coleoptera: Elateridae). Also isolated from other composite and onagracead flowers and from the guts of many insects visiting these flowers, including cantharid and meloid beetles; bombyliid and syrphid flies; andrenid and megachilid bees; and danaid, papilionid, pierid, and yponomeutid butterflies. Pathogenicity for insects not determined.

The $\mathrm{G}+\mathrm{C}$ content of the DNA is $28 \pm 1 \mathrm{~mol} \%$, as determined by buoyant density. The genome size is $1,850 \mathrm{~kb}$ $(1,233 \mathrm{MDa})$.

The type strain is M55 (ATCC 33502).

\section{ACKNOWLEDGMENTS}

This work was supported in part by Binational Agricultural Research and Development Grant US-1902-90R and by U.S. Department of Agriculture Potato Research Grants.

\section{REFERENCES}

1. Bové, J. M., C. Mouches, P. Carle-Junca, J. R. Degorce-Dumas, J. G. Tully, and R. F. Whitcomb. 1983. Spiroplasmas of group I. The Spiroplasma citri cluster. Yale J. Biol. Med. 56:573-582.

2. Bové, J. M., C. Saillard, P. Junca, J. R. Degorce-Dumas, B. Ricard, A. Nhami, R. F. Whitcomb, D. L. Williamson, and J. G. Tully. 1982. Guanine-plus-cytosine content, hybridization percentages, and EcoRI restriction enzyme profiles of spiroplasmal DNA. Rev. Infect. Dis. 4(Suppl.):S129-S136.

3. Carle, P., C. Saillard, and J. M. Bové. 1983. DNA extraction and purification. Methods Mycoplasmol. 1:295-299.

4. Carle, P., C. Saillard, and J. M. Bové. 1983. Determination of guanine plus cytosine content of DNA. Methods Mycoplasmol. 1:301-308.

5. Carle, P., J. G. Tully, R. F. Whitcomb, and J. M. Bové. 1990. Size of the spiroplasmal genome and guanine plus cytosine content of spiroplasmal DNA. Zentralbl. Bakteriol. Mikrobiol. Hyg. Abt. 1 Suppl. 20:889-893.

6. Clark, T. B. Unpublished data.

7. Clark, T. B. 1977. Spiroplasma sp., a new pathogen in honey bees. J. Invertebr. Pathol. 29:112-113.

8. Clark, T. B. 1982. Spiroplasmas: diversity of arthropod reservoirs and host-parasite relationships. Science 217:57-59.

9. Clark, T. B. 1984. Diversity of spiroplasma host-parasite relationships. Isr. J. Med. Sci. 20:995-997.

10. Clark, T. B., R. F. Whitcomb, J. G. Tully, C. Mouches, C. Saillard, J. M. Bové, H. Wróblewski, P. Carle, D. L. Rose, R. B. Henegar, and D. L. Williamson. 1985. Spiroplasma melliferum, a new species from the honeybee (Apis mellifera). Int. J. Syst. Bacteriol. 35:296-308.

11. Eden-Green, S. J., and H. Waters. 1981. Isolation and preliminary characterization of a spiroplasma from coconut palms in Jamaica. J. Gen. Microbiol. 124:263-270.

12. Edward, D. G. F. 1947. A selective medium for pleuropneumonia-like organisms. J. Gen. Microbiol. 1:238-243.

13. Freundt, E. A. 1983. Film and spot production. Methods Mycoplasmol. 1:373-374.

14. Gardella, R. S., and R. A. Del Giudice. 1983. Hemagglutination, hemadsorption, and hemolysis. Methods Mycoplasmol. 1:379384.

15. Grau, O., F. Laigret, P. Carle, J. G. Tully, D. L. Rose, and J. M. Bové. 1991. Identification of a plant-derived mollicute as a strain of an avian pathogen, Mycoplasma iowae, and its implications for mollicute taxonomy. Int. J. Syst. Bacteriol. 41:473-478.

16. Guo, Y. H., T. A. Chen, R. F. Whitcomb, D. L. Rose, J. G. Tully, D. L. Williamson, X. D. Ye, and Y. X. Chen. 1990. Spiroplasma chinense sp. nov. from flowers of Calystegia hederacea in China. Int. J. Syst. Bacteriol. 40:421-425.

17. Hackett, K. J., and T. B. Clark. 1989. The ecology of spiroplasmas, p. 113-200. In R. F. Whitcomb and J. G. Tully (ed.), The mycoplasmas, vol. 5. Academic Press, Inc., New York.

18. Hackett, K. J., T. B. Clark, A. Hicks, R. F. Whitcomb, E. Lowry, and S. W. T. Batra. 1984. Occurrence and frequency of subgroup I-6 spiroplasma in arthropods associated with old 
fields in Maryland and Virginia. Isr. J. Med. Sci. 20:1006-1008.

19. Hackett, K. J., R. F. Whitcomb, R. B. Henegar, A. G. Wagner, E. A. Clark, J. G. Tully, F. Molina, W. McKay, P. Santini, D. L. Rose, J. J. Anderson, and D. E. Lynn. 1990. Mollicute diversity in arthropod hosts. Zentralbl. Bakteriol. Mikrobiol. Hyg. Abt. 1 Suppl. 20:442-454.

20. International Committee on Systematic Bacteriology Subcommittee on the Taxonomy of Mollicutes. 1979. Proposal of minimal standards for descriptions of new species of the class Mollicutes. Int. J. Syst. Bacteriol. 29:172-180.

21. International Committee on Systematic Bacteriology Subcommittee on the Taxonomy of Mollicutes. 1984. Minutes of interim meetings, 2 and 5 September, 1980, Custer, South Dakota. Int. J. Syst. Bacteriol. 34:358-360.

22. Junca, P., C. Saillard, J. G. Tully, O. Garcia-Jurado, J. R. Degorce-Dumas, C. Mouches, J. C. Vignault, R. Vogel, R. McCoy, R. Whitcomb, D. Williamson, J. Latrille, and J. M. Bové. 1980. Charactérisation de spiroplasmes isolés d'insectes et de fleurs de France continentale, de Corse et du Maroc. Proposition pour une classification des spiroplasmes. C.R. Acad. Sci. Ser. D 290:1209-1212.

23. Konai, M., E. A. Clark, and R. F. Whitcomb. 1992. Temperature ranges and optima of spiroplasmas. IOM Lett. 2:137.

24. Lei, J. D., H. J. Su, and T. A. Chen. 1979. Spiroplasmas associated with the green leaf bug, Trigonotylus ruficornis Geoffroy. NSC Symp. Ser. 1:89-97.

25. Pickens, E. G., R. K. Gerloff, and W. Burgdorfer. 1968. Spirochete from the rabbit tick, Haemaphysalis leporispalustris (Packard). I. Isolation and preliminary characterization. J. Bacteriol. 95:291-299.

26. Pollack, J. D., M. C. McElwain, D. DeSantis, J. T. Manolukas, J. G. Tully, C.-J. Chang, R. F. Whitcomb, K. J. Hackett, and M. V. Williams. 1989. Metabolism of members of the Spiroplasmataceae. Int. J. Syst. Bacteriol. 39:406-422.

27. Saglio, P., M. Lhospital, D. Laflèche, G. Dupont, J. M. Bové, J. G. Tully, and E. A. Freundt. 1973. Spiroplasma citri gen. and sp. n.: a mycoplasma-like organism associated with "stubborn" disease of citrus. Int. J. Syst. Bacteriol. 23:191-204.

28. Saillard, C., J. C. Vignault, J. M. Bové, A. Raie, J. G. Tully, D. L. Williamson, A. Fos, M. Garnier, A. Gadeau, P. Carle, and R. F. Whitcomb. 1987. Spiroplasma phoeniceum sp. nov., a new plant-pathogenic species from Syria. Int. J. Syst. Bacteriol. 37:106-115.

29. Skripal, I. G. 1983. Revival of the name Spiroplasmataceae fam. nov., nom. rev., omitted from the 1980 Approved Lists of Bacterial Names. Int. J. Syst. Bacteriol. 33:408.

30. Tully, J. G. 1983. Cloning and filtration techniques for mycoplasmas. Methods Mycoplasmol. 1:173-177.

31. Tully, J. G. 1983. Tests for digitonin sensitivity and sterol requirement. Methods Mycoplasmol. 1:355-362.
32. Tully, J. G. 1984. Family II. Acholeplasmataceae Edward and Freundt 1970, 1AL , p. 775-781. In N. R. Krieg and J. G. Holt (ed.), Bergey's manual of systematic bacteriology, vol. 1. Williams \& Wilkins, Baltimore.

33. Tully, J. G., D. L. Rose, E. Clark, P. Carle, J. M. Bové, R. B. Henegar, R. F. Whitcomb, D. E. Colflesh, and D. L. Williamson. 1987. Revised group classification of the genus Spiroplasma (class Mollicutes), with proposed new groups XII to XXIII. Int. J. Syst. Bacteriol. 37:357-364.

34. Tully, J. G., and R. F. Whitcomb. 1991. The genus Spiroplasma, p. 1960-1980. In A. Balows, H. G. Trüper, M. Dworkin, W. Harder, and K. H. Schleifer (ed.), The prokaryotes, 2nd ed., vol. 2. Springer-Verlag, New York.

35. Tully, J. G., R. F. Whitcomb, H. F. Clark, and D. L. Williamson. 1977. Pathogenic mycoplasmas: cultivation and vertebrate pathogenicity of a new spiroplasma. Science 195:892-894.

36. Weisburg, W. G., J. G. Tully, D. L. Rose, J. P. Petzel, H. Oyaizu, D. Yang, L. Mandelco, J. Sechrest, T. G. Lawrence, J. Van Etten, J. Maniloff, and C. R. Woese. 1989. A phylogenetic analysis of the mycoplasmas: basis for their classification. J. Bacteriol. 171:6455-6467.

37. Whitcomb, R. F. 1983. Culture media for spiroplasmas. Methods Mycoplasmol. 1:147-158.

38. Whitcomb, R. F., J. M. Bové, T. A. Chen, J. G. Tully, and D. L. Williamson. 1987. Proposed criteria for an interim serogroup classification for members of the genus Spiroplasma (class Mollicutes). Int. J. Syst. Bacteriol. 37:82-84.

39. Whitcomb, R. F., T. A. Chen, D. L. Williamson, C. Liao, J. G. Tully, J. M. Bové, C. Mouches, D. L. Rose, M. E. Coan, and T. B. Clark. 1986. Spiroplasma kunkelii sp. nov.: characterization of the etiological agent of corn stunt disease. Int. J. Syst. Bacteriol. 36:170-178.

40. Whitcomb, R. F., J. G. Tully, P. McCawley, and D. L. Rose. 1982. Application of the growth inhibition test to Spiroplasma taxonomy. Int. J. Syst. Bacteriol. 32:387-394.

41. Whitcomb, R. F., J. G. Tully, D. L. Rose, E. B. Stephens, A. Smith, R. E. McCoy, and M. F. Barile. 1982. Wall-less prokaryotes from fall flowers in central United States and Maryland. Curr. Microbiol. 7:285-290.

42. Williamson, D. L., J. G. Tully, and R. F. Whitcomb. 1979. Serological relationships of spiroplasmas as shown by combined deformation and metabolism inhibition tests. Int. J. Syst. Bacteriol. 29:345-351.

43. Williamson, D. L., J. G. Tully, and R. F. Whitcomb. 1989. The genus Spiroplasma, p. 71-111. In R. F. Whitcomb and J. G. Tully (ed.) The mycoplasmas, vol. 5. Academic Press, Inc., New York.

44. Williamson, D. L., R. F. Whitcomb, and J. G. Tully. 1978. The spiroplasma deformation test, a new serological method. Curr. Microbiol. 1:203-207. 